\title{
Contagion and causality: an empirical investigation of four Asian crisis episodes
}

Citation for published version (APA):

Sander, H., \& Kleimeier, S. (2002). Contagion and causality: an empirical investigation of four Asian crisis episodes. METEOR, Maastricht University School of Business and Economics. METEOR Research Memorandum No. 061 https://doi.org/10.26481/umamet.2002061

Document status and date:

Published: 01/01/2002

DOI:

10.26481/umamet.2002061

Document Version:

Publisher's PDF, also known as Version of record

\section{Please check the document version of this publication:}

- A submitted manuscript is the version of the article upon submission and before peer-review. There can be important differences between the submitted version and the official published version of record.

People interested in the research are advised to contact the author for the final version of the publication, or visit the DOI to the publisher's website.

- The final author version and the galley proof are versions of the publication after peer review.

- The final published version features the final layout of the paper including the volume, issue and page numbers.

Link to publication

\footnotetext{
General rights rights.

- You may freely distribute the URL identifying the publication in the public portal. please follow below link for the End User Agreement:

www.umlib.nl/taverne-license

Take down policy

If you believe that this document breaches copyright please contact us at:

repository@maastrichtuniversity.nl

providing details and we will investigate your claim.
}

Copyright and moral rights for the publications made accessible in the public portal are retained by the authors and/or other copyright owners and it is a condition of accessing publications that users recognise and abide by the legal requirements associated with these

- Users may download and print one copy of any publication from the public portal for the purpose of private study or research.

- You may not further distribute the material or use it for any profit-making activity or commercial gain

If the publication is distributed under the terms of Article $25 \mathrm{fa}$ of the Dutch Copyright Act, indicated by the "Taverne" license above, 
Version: February 5, 2002

\title{
Contagion and Causality: An Empirical Investigation of Four Asian Crisis Episodes
}

\author{
Harald Sander ${ }^{\mathrm{a}, *}$ \\ and
}

Stefanie Kleimeier ${ }^{\mathrm{b}, 1}$

a Department of Business Administration and Management, University of Applied Sciences Cologne, Claudiusstr. 1, 50678 Cologne, Germany

$\mathrm{b}$ Limburg Institute of Financial Economics, Maastricht University, P.O. Box 616, 6200 MD Maastricht, The Netherlands

\begin{abstract}
:
Our study extends on conventional measures of contagion by directly investigating changes in the existence and the directions of causality. In particular, we apply a Granger-causality methodology on sovereign bond spreads as a measure of perceived country risk. For the Asian crisis, we find evidence for new and changed causality patterns on a regional level. With the arrival of the Russian crisis, causality patterns were changing not only on a regional but also on a global level.
\end{abstract}

Keywords: Contagion, Financial Crisis, Currency Crisis, Sovereign Bond Spreads, Granger-Causality, Cointegration.

JEL Classification: F31, F32, F34, G15

* Corresponding author: Phone: ++49-208-853691, Fax: ++49-221-8275-3131

${ }^{1} \mathrm{~S}$. Kleimeier would like to acknowledge financial support from METEOR.

E-mail addresses: gh.sander@t-online.de (H. Sander), s.kleimeier@berfin.unimaas.nl (S. Kleimeier) 


\section{Introduction}

On July 2, 1997 Thailand floated the Baht and at the same time contributed to the replacement of the "Asian Miracle" by the "Asian Crisis". To many observers and investors the vulnerability of the Asian countries to abrupt reversals in international capital flows came as a surprise. Even after the 1994 Mexican Peso crises and its impact on other emerging market countries, also known as the "tequila hangover", most observers continued to believe in the sustainability of South-East Asian balance of payments positions mainly because of their believe in the strong macroeconomic fundamentals of the countries in the region, such as a prudent fiscal policy, low inflation rates and high domestic savings and investments ${ }^{1}$. However, the severity, the spread of the crisis, as well as the speed of this spread and its geographical reach are difficult to explain by pointing to "fundamentals". "Contagion" became the catchword for such phenomena and is now widely being used to describe the events around the crises of the European Monetary System in 1992/93, the "tequila hangover" in 1994, the Asian Crises in 1997, and the impact of the Russian crisis on other emerging economies in 1998.

In a widely accepted, though not undisputed definition in the tradition of epidemiological studies, Edwards (2000) asserts that “...contagion reflects a situation where the effect of an external shock is larger than what was expected by experts and analysts". This definition implies that contagious effects are to be differentiated from "normal" transmissions of shocks across countries, also known as interdependencies. If one follows this narrow definition, the task of empirical contagion studies is to investigate whether or not

\footnotetext{
${ }^{1}$ In a 1995 post-Mexico crises analysis on "Emerging Markets and the Liberalisation of Capital Movements" the OECD writes: "The key lessons from these and other episodes is that monetary and fiscal policies that support a stable and credible economic environment are needed to forestall potentially destabilising capital market pressures" (OECD 1995).
} 
channels and intensity of shock propagation across countries is changed in certain crises periods. Four major strategies have been employed in the literature to identify contagion: Correlation of asset prices, conditional probability of currency crises, volatility changes, and co-movements of capital flows and rates of return ${ }^{2}$. Among these four groups, our study is related to the analysis of asset price correlation. While most studies investigate changes in cross-market interdependencies (e.g. Baig and Goldfajn 1999, Forbes and Rigobon 1999), there are only very few studies that explore changes in the existence and the directions of causality. Exemptions are recent studies by Edwards (2000) who focuses solely on Chile, Baig and Goldfajn (2001) who investigate the contagion from Russia to Brazil, Gelos and Sahay (2001) who examine spillovers in transition countries, and Granger, Huang and Yang (2000) who investigate stock prices and exchange rates during the Asian crisis. Our study extends this literature by providing evidence on the changes in crisis causation by applying a Granger-causality approach with respect to sovereign bond spreads as a measurement of perceived country risk. We distinguish four different sub-periods and show how causality patterns have changed over time and how a first predominantly regional contagion process became more global after the Russian default in 1998. In this respect our study sheds also more light on the debate whether contagious currency crises more a regional phenomenon as suggested by Glick and Rose (1999b) or whether they will eventually spread globally.

This paper starts in chapter 2 with a short review of the current state of the debate on contagion with special emphasis on the existing literature regarding the measurement of contagion. Chapter 3 describes the data construction and discusses the methodology used. The intra-regional results are discussed in chapter 4, while in chapter 5 the inter-regional

\footnotetext{
${ }^{2}$ For a detailed discussion of the literature see Claessens, Dornbusch and Park (2001), Pesenti and Tille (2000), Edwards (2000).
} 
results - involving Latin American and Eastern European emerging economies - are presented. Chapter 6 concludes.

\section{Contagion: Definition, Theories, and Measurement}

In a first approximation a contagious currency crisis has been defined as the spread of a currency crisis from the ground-zero country (van Rijckeghem and Weder 1999, 2001). Generally speaking, currency crises occur when a change in confidence in a currency leads to a (sudden) reversal of the capital account. This often manifests itself in drastically reduced capital inflows accompanied by massive outflows (capital flight). If the country does not resort to capital controls, it will experience a depreciation of its currency or, when defending the exchange rate, either a depletion of its foreign exchange reserves or increasing interest rates. Van Rijckeghem and Weder (1999) therefore suggest to define contagion as a "sufficiently persistent fallout to raise worries about a possible currency crisis, and involving a change in the order of $10 \%$ in either reserves, the exchange rate, or the interest rate (i.e.1000 basis points)." On the base of this definition they find that all recent crises affect both, regional economies, but also, though to a lesser extent, economies that are far away and have few economic contacts either with ground-zero country or the other infected regional economies. In particular the spread of the Russian crises was more global. ${ }^{3}$

However, there is a point whether any transmission of shocks across countries should be viewed as contagion, or whether the use of the term contagion should be restricted to situations where “...extent and magnitude to which a shock is transmitted internationally exceeds what was considered ex ante" (Edwards 2000). As many observers stress the Asian 
crisis was in fact largely unanticipated (see for example Chowdhry and Goyal, 2000). In our study we therefore follow the narrow contagion definition that builds on Masson (1998), who has labeled such unanticipated situations as "pure contagion". They are to be distinguished from "simple contagion" caused by "monsoonal effects" or "linkages". "Monsoonal effects" stand for random aggregate shocks that are hitting a number of countries in a similar way, such as increases in international interest rates, a decline in international demand or exchange rate changes of major currencies. "Linkages" are normal interdependencies, such as those produced by trade and financial linkages between countries. Proponents of the view that the Asian currency crisis is propagated by linkages would thus reject its classification as (pure) contagion. For example, Glick and Rose (1999a) advocate that trade linkages could explain the spread of the crisis across countries. Their approach highlights the role of nominal devaluations, which - in the presence of short-run price stickiness - change the relative competitiveness of the countries in the region, thus leading to a spread of the crises. Since trade also tends to be regionally concentrated, a corollary to this view is that currency crises tend to be regionally concentrated. Baig and Goldfajn (1999), however, do not find much empirical support evidence for this channel as on the one hand intra-regional trade is relatively low and on the other hand the affected Asian countries do not have very similar third country export profiles. Other authors highlight financial linkages. Such links can typically considered to be present between countries with open financial systems, which can act as a transmission channel ${ }^{4}$. Van Rijckeghem and Weder (1999) find evidence for a "common lender channel" for which "the underlying assumption ... is that bank exposures in countries affected by primary financial crises were large, implying substantial potential

\footnotetext{
${ }^{3}$ In the cases of the Mexican and Asian crisis this definition results in the same list of countries that Glick and Rose (1999a) derive from newspaper reports. The Russian crisis was not investigated by Glick and Rose.
} 
losses, and hence the need to restore capital asset ratios, meet margin calls, or readjust risk exposure". Likewise country revaluations after learning more about the macroeconomic fundamentals or receiving "wake-up calls" may belong in this category. Categorizing such theories under the heading linkages, however, presupposes that the financial shocks are exogenous, i.e. the transmission process will not change when switching from tranquil to crises period.

Only when the transmission process itself changes when entering crises periods, we talk of contagion in the sense of Masson's pure contagion ${ }^{5}$. For example, in contrast to financial linkages we would talk here about endogenous liquidity shocks. The point can be illustrated by a model of asymmetric information among investors proposed by Calvo (1999). An endogenous liquidity crisis can be triggered when informed investors sell emerging market securities to meet margin calls. If this action is misread by uninformed investors as signaling low returns in emerging markets, it can lead to a collapse in other emerging markets. Calvo suggests that this mechanism might not happen in tranquil periods and will therefore change the propagation mechanism. Secondly, pure contagion can also happen if investors change their assessment of the rules under which international finance takes place (Claessens, Dornbusch, and Park 2001). Another group of theories of pure contagion are those that advocate self-validating losses in confidence that can push economies from a "good" into a "bad" equilibrium. The so-called second-generation currency crises models belong in this category. While according to Eichengreen, Rose, and Wyplosz (1996) "firstgeneration" currency crises models explain the run on a currency by inconsistent macroeconomic policies, such as the monetization of a huge fiscal deficit in the presence of a

\footnotetext{
${ }^{4}$ Imagine, for example, the case where the bankruptcy of a Korean bank leads to reduced financial flows in form of corporate bank loans to Thailand.

${ }^{5}$ Forbes and Rigobon (1999) use the term of "shift contagion"
} 
currency peg, "second-generation" models are focusing on a self-fulfilling crisis mechanism. In such models currency crises can occur with an arbitrary timing despite sound macroeconomic fundamentals, and may lead to multiple equilibria. Obstfeld (1994) first constructed such a model for the EMS crises. In contrast to the Obstfeld model the trigger mechanism in the Asian crisis episode was, however, clearly not an employment-exchange rate stability trade-off. A more recent contribution with an explicit emerging market focus is Sbracia and Zaghini (2001) who develop a second-generation currency crisis model where a sudden shift in speculator's behavior can trigger a currency devaluation without any prior deterioration of economic fundamentals. Masson (1998) has advocated a balance of payments model that is capable of "producing" coordinated investors' expectation, while other models highlight the importance of moral hazard in lending through implicit government guarantees that are being withdrawn when losses after the currency attack become visible or model a currency crisis as the other side of the coin of a banking crisis where a self-fulfilling loss in confidence will force banks to liquidate their investment, thus validating the loss in confidence $^{6}$. Krugman (1999) develops a model that emphasizes transfer problems and the balance sheet problem ${ }^{7}$. In this model, bankruptcies and a banking crisis are the consequences of a financial crises and thus self-validating the loss in confidence. In sum, all the above-discussed models of (pure) contagion advocate the role of multiple equilibria in explaining why channels and intensity of shock propagation across countries is changed in certain crises periods.

We have shown that in a broad sense contagion usually refers to the spread of market disturbances from one country to other countries. It has now become obvious that this can be

\footnotetext{
${ }^{6}$ For a detailed discussion see Krugman (1999) and the survey literature referred to in footnote 2.

${ }^{7}$ For an earlier emphasis on balance sheet problem in relation to the 1980 s developing country debt crisis see Sander (1990).
} 
the result of existing normal interdependencies among (emerging) market economies or of newly arisen or drastically altered interdependencies. Among the four major strategies have been applied in empirical studies to discriminate (pure) contagion from interdependencies (correlation of asset prices, conditional probability of currency crises, volatility changes, and co-movements of capital flows and rates of return) our study is related to the study of correlation of asset prices. In this area, Forbes and Rigobon (1999) have suggested to discriminate empirically between the two approaches by testing whether or not cross-market correlation increase statistically significantly in crises periods. If yes, crises-contingent theories have a point ${ }^{8}$, if not interdependencies are responsible for the spread of currency crises. Simple correlations have, however, been criticized by Forbes and Rigobon (1999). The authors argue that simple correlations are biased due to the presence of heteroskedasticity, endogeneity, and omitted variables. After correcting for these statistical problems the authors test for statistically significant shifts in correlation of stock market returns before and directly after the crises for three crises episodes: the 1994 Mexican crises, the 1997 Asian Crises, and the 1987 US stock market crash. Their result is striking: After adjusting for the abovementioned statistical problems they found only interdependencies, no (pure) contagion. However, in the EMS context, Favero and Giavazzi (1999) find evidence for contagion with regard to the spreads between German short-term interest rates and the interest rates of some of the European countries involved in the crisis. They also control for changes in the fundamentals so that the shock (the Danish referendum against EMU) that changes the way of transmission is truly causing a specific "disease" called "contagion". Consequently, the authors argue in favour of theories that interpret the propagation of shocks as "crisescontingent", rather than for theories that focus on linkages and leave no special role to crises.

\footnotetext{
${ }^{8}$ The relevance of multiple equilibria would of cause not rule out an important role for linkages.
} 
Favero and Giavazzi (1999) thus "...contradict the view that evidence for contagion is only the result of the application of poor statistical techniques". In the context of the Asian crisis, Baig and Goldfajn (1999) perform cross-market correlations for exchange rates, stock market returns, interest rates, and sovereign bond spreads using the Forbes and Rigobon methodology. While they find some evidence for an increase in correlation in exchange rate co-movements, these result have to be interpreted with reservation since the exchange rates were managed or pegged in the tranquil period. The evidence for contagion in stock markets is mixed as best, thus - at least not sharply contradicting the Forbes and Rigobon results. For interest rates the evidence for contagion is also mixed - not surprising, given that the interest rate is also a policy variable. The overwhelming evidence for contagion, however, is found in sovereign spreads: "The spreads on dollar-denominated debt, representing default risk, display the most striking degree of correlation and evidence for contagion" (Baig and Goldfajn 1999). As spreads are directly reflecting the risk perception of financial markets, pure contagion may thereby often be "solely the result of the behavior of investors or other financial agents" as argued by Claessens, Dornbusch, and Park (2001). In the following we will therefore concentrate on an extension of the empirical analysis of sovereign bond spreads.

\section{Data and Methodology}

\subsection{Data}

The existing reviewed studies measure changes in cross-market interdependencies but fall short of exploring changes in the existence and the directions of causality. Our study will

provide evidence on the changes in crisis causation by applying a Granger-causality 
approach. For our study we adopt the narrow definition of contagion as a marked change in cross-market interdependencies. Following Baig and Goldfajn (1999) we concentrate on daily spreads of US\$ denominated sovereign bonds traded in the international markets as the relevant measure for contagion. We interpret these spreads as pure measures of country credit risk and therefore as indicators of the effects of the crisis as perceived by the international financial market.

More specifically, spreads are defined as the difference between the respective sovereign bond yield and the corresponding US Treasury bill yield as reported by Datastream. Note that Datastream focuses on maturities when identifying the yield for the corresponding US Treasury bill. If a Treasury bill with the same maturity as the sovereign bond is not available, Datastream calculates a theoretical yield using linear interpolation of yields with longer and shorter maturities. For each country one bond is selected based on the following 3-step procedure:

(1) All US dollar denominated sovereign bonds of the country for which spreads are available on Datastream are identified. This resulted in the following number of bonds per country $^{9}$ : Argentina 6, Brazil 7, Hungary 1, Indonesia 1, Korea 7, Malaysia 1, Mexico 1, Philippines 1, Poland 5, Russia 1, Thailand 2.

(2) For the countries with multiple bonds outstanding, a choice for one of these bonds has to be made. In order to investigate how critical the choice of the bond would be for the final results of this study, the spreads of all bonds are first tested for unit roots and then a series of cointegration tests is conducted. In general, we found cointegration between all

\footnotetext{
${ }^{9}$ Note that while a country might have issued a larger number of US dollar denominated sovereign bonds, Datastream lists spreads only for a smaller sub-sample of bonds and furthermore, does not list 'dead' bonds. Once bonds mature, their data are deleted from the Datastream database.
} 
national bond spreads. Thus, the choice of the bond appears not to be critical to the final results of the study.

(3) For countries, which have only one US dollar denominated sovereign bond outstanding, the spread for this bond is obviously used. For countries with multiple bonds, we select that bond which has spreads available over the whole time period under investigation. As far as possible, we try to select bonds that are most similar across countries with respect to maturity. The Datastream codes, which reveal the issuer, issue-date, coupon rate and maturity, of the selected bond series are given in Table A1 in the appendix.

We investigate four sub-periods: A pre-crisis tranquil period that starts on December 19, 1996 and ends on July 1, 1997; a crisis period that captures the period from July 2, 1997 to July 31, 1998; a transition period from August 1, 1998 to July 31, 1999, and a post-crises period from August 1, 1999 to March 16, 2000. While the definition of the tranquil and postcrises periods comes almost naturally, the split between a crisis period and a transition period needs more explanation. In particular, in August 1998 two effects occurred: The Russian ruble crises and Malaysia's decision to adopt capital controls may both have had differential and possibly disturbing effects. The rationale for our decision is therefore to isolate a core crises period rather than expecting to learn too much from the transition period.

Table 1 provides descriptive statistics of the daily bond spreads over the different subperiods. These spreads reveal that country credit risk rises until the transition period but falls as expected during the post-crisis period when the crisis has passed. However, the market's perception of country credit risk does not return to the pre-crisis levels but remains consistently higher. This is reflected by the fact that for all countries except Hungary the post-crisis spreads are higher than those of the tranquil period. Furthermore, whereas the crisis might have spilled over into non-Asian countries, the Asian countries as a group 
suffered the most deterioration of their country credit risk. Finally, as expected, volatility increases during a crisis. The standard deviations of bond spreads increased during the crisis and transition period, only to fall in the post-crisis period, with Brazil and Hungary as the only exemptions. Spread volatility, however, remained high even in the post-crisis period.

- insert Table 1 here -

\subsection{Methodology}

The traditional concept for analyzing causation in time series is Granger causality. The conventional Granger test specifies a bivariate vector autoregressive (VAR) model with a lag length set as k:

$$
\begin{gathered}
X_{t}=\alpha_{X}+\sum_{i=1}^{k} \beta_{X, i} X_{t-i}+\sum_{i=1}^{k} \gamma_{X, i} Y_{t-i}+\varepsilon_{X, t} \\
Y_{t}=\alpha_{Y}+\sum_{i=1}^{k} \beta_{Y, i} Y_{t-i}+\sum_{i=1}^{k} \gamma_{Y, i} X_{t-i}+\varepsilon_{Y, t}
\end{gathered}
$$

The Granger causality is examined by testing whether all $\gamma_{\mathrm{i}}$ are equal to zero using a standard F-test. If we cannot reject the null hypothesis in equation (1) $\mathrm{Y}$ is said to Granger-cause $\mathrm{X}$, i.e. we reject the hypothesis that $\mathrm{Y}$ does not cause $\mathrm{X}$. In an analogous way we proceed with equation (2). If causation cannot be rejected in both equations, the variables are interdependent. 
The above equations are, however, only valid for series that are stationary - that is $\mathrm{I}(0)$. In earlier causality studies, time-series that were found to be non-stationary - that is $\mathrm{I}(1)$ - were differenced and thus converted into an I(0) series to which the Granger Causality tests could be applied ${ }^{10}$ :

$$
\begin{gathered}
\Delta X_{t}=\alpha_{X}+\sum_{i=1}^{k} \beta_{X, i} \Delta X_{t-i}+\sum_{i=1}^{k} \gamma_{X, i} \Delta Y_{t-i}+\varepsilon_{X, t} \\
\Delta Y_{t}=\alpha_{Y}+\sum_{i=1}^{k} \beta_{Y, i} \Delta Y_{t-i}+\sum_{i=1}^{k} \gamma_{Y, i} \Delta X_{t-i}+\varepsilon_{Y, t}
\end{gathered}
$$

Later research showed that this procedure is only correct if the two series are not cointegrated as MacDonald and Kearney (1987) state: "Granger causality test which are performed on time series data should only be filtered by first differencing if the researcher has initially demonstrated that the relevant variables are not cointegrated." For cointegrated series, different approaches to causality testing have to be applied. Based on results of Sims et al. (1990), Demetriades (1996) argues that "test statistics derived from a level VAR framework are not valid unless the variables employed are either I(0) or I(1) and cointegrated." This implies that equations (1) and (2) could be used to test Granger-causality for cointegrated series. On the other hand, Engle and Granger (1987) and Granger (1988) argue that in the presence of cointegration, causality tests, which ignore the error correction term (ECT) derived from the cointegration relationship are mis-specified and suggest to re-parameterize

\footnotetext{
${ }^{10}$ There is also the possibility that one variable is found to be $\mathrm{I}(0)$ and the other $\mathrm{I}(1)$. In these cases, the $\mathrm{I}(1)$ variable will be included in the equation in terms of first differences whereas the $\mathrm{I}(0)$ variable will be included in levels. As the first differences of an I(1) series will be I(0), this procedure ensures that all series included in the equation are $\mathrm{I}(0)$.
} 
the model in the equivalent error correction model form (ECM). The causality tests in this case are based on the following equations:

$$
\begin{aligned}
& \Delta \mathrm{X}_{\mathrm{t}}=\alpha_{\mathrm{X}}+\sum_{\mathrm{i}=1}^{\mathrm{k}} \beta_{\mathrm{X}, \mathrm{i}} \Delta \mathrm{X}_{\mathrm{t}-\mathrm{i}}+\sum_{\mathrm{i}=1}^{\mathrm{k}} \gamma_{\mathrm{X}, \mathrm{i}} \Delta \mathrm{Y}_{\mathrm{t}-\mathrm{i}}+\varphi_{\mathrm{X}} \mathrm{ECT}_{\mathrm{X}, \mathrm{t}-1}+\varepsilon_{\mathrm{X}, \mathrm{t}} \\
& \Delta \mathrm{Y}_{\mathrm{t}}=\alpha_{\mathrm{Y}}+\sum_{\mathrm{i}=1}^{\mathrm{k}} \beta_{\mathrm{Y}, \mathrm{i}} \Delta \mathrm{Y}_{\mathrm{t}-\mathrm{i}}+\sum_{\mathrm{i}=1}^{\mathrm{k}} \gamma_{\mathrm{Y}, \mathrm{i}} \Delta \mathrm{X}_{\mathrm{t}-\mathrm{i}}+\varphi_{\mathrm{Y}} \mathrm{ECT}_{\mathrm{Y}, \mathrm{t}-1}+\varepsilon_{\mathrm{Y}, \mathrm{t}}
\end{aligned}
$$

One advantage of ECM-based tests is that they allow us to differentiate between two types of causality based on the short-run dynamics of the VAR and on the disequilibrium adjustment of the ECM. In particular, the F-test on the estimated coefficients $\gamma_{i}$ provides evidence regarding a short-term adjustment dynamics. The t-test of the estimated coefficient $\varphi$ provides evidence of the existence of an error correction mechanism that drives the variables back to their long-term equilibrium relationship that can is embodied in the cointegration vector. Cointegration implies that although the two time-series can wander extensively they are still bound together by a stable long-term relationship. For example, if cointegration can be found between bond spreads of two countries, this can be interpreted as a situation where both countries are affected by and behave similarly to the same shocks in the long-run. If now the spread for one country would increase above this equilibrium level the ECT would measure the speed at which the spreads return to the equilibrium level. They are thus identifying the existence of an effective arbitrage process. Only if markets are noncointegrated international diversification is beneficial from the point of view of a portfolio investor because of lower levels of correlation across national markets. 
Taking these considerations into account, we proceed as follows:

Step 1: We test the time series for unit roots based on equations (7) and (8). A series is assumed to be $\mathrm{I}(1)$ if the null hypothesis $\mathrm{H}_{0}: \delta_{1}=0$ is accepted based on a t-test for the level regression (7) but rejected for the first differences regression (8). A series is assumed to be $\mathrm{I}(0)$ if the t-test indicates rejection of the null for both equations.

$$
\begin{gathered}
\Delta \mathrm{X}_{\mathrm{t}}=\delta_{\mathrm{X}, 0}+\delta_{\mathrm{X}, 1} \mathrm{X}_{\mathrm{t}-1}+\delta_{\mathrm{X}, 2} \Delta \mathrm{X}_{\mathrm{t}-2}+\varepsilon_{\mathrm{X}, \mathrm{t}} \\
\Delta^{2} \mathrm{X}_{\mathrm{t}}=\delta_{\mathrm{X}, 0}+\delta_{\mathrm{X}, 1} \Delta \mathrm{X}_{\mathrm{t}-1}+\delta_{\mathrm{X}, 2} \Delta^{2} \mathrm{X}_{\mathrm{t}-2}+\varepsilon_{\mathrm{X}, \mathrm{t}}
\end{gathered}
$$

Step 2: We test for cointegration among any pairs of countries by applying standard DurbanWatson (DW) and Dickey-Fuller (DF) tests to the cointegration regression:

$$
X_{t}=\eta_{X, 0}+\eta_{X, 1} Y_{1}+\varepsilon_{X, t}
$$

Step 3: If the series are found to be $\mathrm{I}(0)$, causality testing according to equations (1) and (2) will be applied.

If the series are found to be I(1) and not cointegrated, causality testing according to equations (3) and (4) will be applied.

If the series are found to be I(1) and cointegrated, causality will be tested based on equations (5) and (6). The error correction term using in equation (5) is obtained from the estimated error terms of the cointegration regression (9). For equation (6), the 
estimated errors based on the cointegration regression $Y_{t}=\eta_{Y, 0}+\eta_{Y, 1} X_{1}+\varepsilon_{Y, t}$ will be used.

In step 3 we estimate the cointegrating vectors not over the whole period but only for the four sub-periods ${ }^{11}$. Using a cointegration approach over a relatively short period is not uncontroversial. However, given the high-frequency data we employ, we believe that this approach is justified, in particular as the resulting cointegrating relationships could be interpreted as reflecting systematic temporary pattern. However, as our results will show, there is very little evidence for cointegration. Only in the crisis and post-crises periods there is evidence for cointegration among some countries. This suggests that only in few cases such systematic temporary pattern have established themselves during the various Asian crisis episodes. Nevertheless, whenever we could not reject the cointegration hypothesis we found it necessary to include the ECT in order to avoid the mis-specification of the VAR model. In making a choice between estimating the cointegration over a relatively short period of time or using a mis-specified Granger-causality analysis that neglects a statistically significant cointegration relationship, we opted against the latter alternative. Moreover, a systematic temporary pattern in financial markets' risk assessment may have some validity despite the short period. For example, for Indonesia and Korea no cointegration and thus no error correction mechanism could be established in all periods except the post-crisis period. This could be interpreted as evidence that the market's risk perception of formerly unlinked countries has become related in the post-crisis period.

\footnotetext{
${ }^{11}$ Our approach is related to the methodology applied by Granger, Huang, and Yang (2000) who investigate the bivariate causality between stock prices and exchange rates during the Asia crisis. These authors, however, estimate a long-term cointegration relationship over a 12-year period, which includes all crises periods allowing for the presence of structural breaks. Despite the fact that they did not find evidence in favour of cointegration, they always included the ECT and interpret the significance of the estimated coefficient of the ECT as evidence for cointegration. While we are in agreement with these authors in not neglecting an existing cointegration relationship, we opted for the reasons given above for estimating temporary systemic pattern in order to obtain ECTs for such shorter periods.
} 


\section{Contagion and Causality Inside Asia}

Starting with the unit root analysis of step 1, our tests reveal that in general, all Asian series are found to be I(1). The only exceptions are Malaysian spreads in the tranquil period, which are found to be $\mathrm{I}(0)$. Among the non-Asian series, only the transition period is characterized by $\mathrm{I}(0)$ series $^{12}$. Therefore, we have to move to step 2 and investigate the presence of cointegration in the relevant cases. Cointegration in spreads appears not to be a dominant feature inside Asia in none of the four periods ${ }^{13}$. Since preliminary experiments with our data have shown that the results of cointegration tests are quite sensitive to the choice of the period length we adopt a very conservative strategy in accepting evidence for cointegration. We interpret the evidence for cointegration as significant only if either one of the two test statistics allows the rejection of the null hypothesis of no cointegration at the $1 \%$ level or if both statistics allow rejection at at least a $5 \%$ level.

Using this strict criterion we found that in the tranquil period only the Korea-Thailand series are cointegrated and that there exists cointegration between the Philippines and Thailand. This implies that individual country risks play the dominant role in determining the risk spreads. In the crisis and transition periods evidence for cointegration disappeared almost completely (with the exception of Korea-Philippines), but surfaced in the post-crisis period in six cases involving all countries. Without wanting to over-interpret these results one might conclude that the finding of non-cointegrated markets before the crisis reflects the absence of common macroeconomic risk factors. During the crisis and transition period it is at most short-term causality that might be identified. In the post-crisis period more evidence for cointegration may point in favor of a more uniform perception of regional country risk.

\footnotetext{
${ }^{12}$ Table A2 of the appendix shows the results of the unit root for all countries and sub-periods.
} 
However, even that might only constitute only a temporary systematic pattern and may disappear in the longer run. ${ }^{14}$ In other words, (pure) contagion can happen if investors change their assessment of the rules under which international finance takes place, as suggested by Claessens, Dornbusch, and Park (2001).

Going now to our study of causality in step 3, we take the cointegration tests as a base for adopting the correct causality test procedure. While having been conservative in interpreting cointegration on the one hand we tried to avoid the error of not including the ECT on the base of a too strict rejection policy. Therefore, we extend the VAR by the ECT if the null of no cointegration could be rejected by at least one test statistic at the $5 \%$ level or higher.

Figure 1 and Table 2 give an overview of the results ${ }^{15}$. In the tranquil period, there is a virtual absence of a causality pattern with the only exception of the two country groups where we found cointegration. In the crisis period, we find nine cases of cross-country causation. Of these, we could identify the emergence of short-term dynamics of the GrangerCausality type in eight cases of which two were (statistically significant) supported by arbitrage processes as measured by the ECT. In one case causality was based on an arbitrage process only (from Thailand to Korea). With the passage of time short-term dynamics start to fall from six to three cases while Korea seems to have reestablished its ECT-based causation effect on Thailand and - which is new - on Indonesia.

- Insert Table 2 and Figure 1 here -

\footnotetext{
${ }^{13}$ The results are presented in Table A3 of the appendix.

${ }^{14}$ Since we do not find much evidence for all but the last sub-period, we are not surprised that Granger, Huang, and Yang (2000) could also not find a long-run cointegration relationship between Asian countries. That markets as well as the risk-perception are become related might be a particular temporary post-crisis event.

${ }^{15}$ Detailed results are listed in Table A4 of the appendix.
} 
It interesting to note that in the crisis period Thailand was not Granger-causing anything, rather some long-term arbitrage processes have appeared only. This result supports the view that the stumbling of Korea may have been more important in finally stirring off the crisis as "reputational externalities" may have played an important role. According to Summers (2000): "A crisis in one country can affect investors' expectations and perceptions about common structural conditions and vulnerabilities in other countries and the likely policy response to such vulnerabilities." Summers also quotes the 1999 Economic Report of the President (Council of Economic Advisors 1999) as stating: "For example investors' believe in the strength of the Asian economic model may have changed when one of the star performers stumbled." 16

During the transition period particularly the Granger-causality type short-run dynamics continued to be at work probably enforced by the Russian crisis before with the stabilizing effects that appeared in 1999 causality gradually disappeared. In line with our earlier argument, there was no "temporary systematic pattern" detectable in this period as indicated by the complete absence of any evidence in favor of cointegration. In sum, our results show that causality patterns that have been absent before the Asian crisis started suddenly emerged, thus establishing cross-market linkages that appear to be pure crisiscontingent. We therefore interpret our results as being supportive of the claim that the crisis was to a considerable degree determined by pure contagion rather than interdependencies.

\footnotetext{
${ }^{16}$ Park and Song (2001) argue that Korea was not directly effect by Thailand but indirectly through Taiwan (which is not included in our study for lack of appropriate data). The authors assert that "when foreign banks and institutional investors saw that such a stable country as Taiwan with strong fundamentals was vulnerable to the crisis in Southeast Asia, they must have concluded that both Hong Kong and Korea would not been immune from the crisis."
} 


\section{Contagion between Asia and Other Emerging Economies}

In a second step we extend our study to investigate the interdependencies of the Asian countries with three emerging market in Central and Eastern Europe (Russia, Poland, Hungary) and three countries in Latin America (Argentina, Brazil, Mexico). The results here are less clear-cut than in the Asia-restricted sample as Table 3 shows. Cointegration was detected in 11 of 60 cases in the tranquil and post-crises periods, in 7 cases during the crisis period and was found again to be totally absent in the transition period. As cointegration is again not a dominant feature, this allows for differences in individual country risk variations. In the post-crisis period there is however a remarkable appearance of cointegration between Korea and all other non-Asian sample countries - pointing to a perception of a common risk in these emerging market economies. When it comes to causality, it appears that the number of statistically relevant short-run causality relationships is increasing in the transition period only. This may reflect the impact of the Russian crises, while before the ruble crises the Asian crises appeared not to have changed much the causality relationship between Asia and the rest of our country sample. It is interesting to note that the Russian crisis appeared not to have a direct impact on Asia, but rather invoked new short-run causalities mainly between Asian and Latin American countries that had not been present before, possibly pointing to the important role of international financial markets in reassessing country risk ${ }^{17}$. Again, we find therefore changing pattern of causality that may support the view of the "pure contagion" advocates. It makes, however, also clear that the Asian crisis was first a very regional affair that has become a more global one as Russia stumbled and invoked new and more global contagion effects. 
- Insert Table 3 here -

\section{Conclusion}

Our study has extended on conventional measures of contagion defined as a marked increase of cross-market correlation by directly investigating changing causality pattern by using the Granger-causality methodology. Our results show that the Asian crisis first established new and changed causality patterns that were not present before the crises on a regional base. Moreover, in some cases it even appeared that in the post-crisis period formerly unrelated markets became cointegrated, pointing to a changed perception of emerging country risk. Furthermore, it is shown that while the initial impact of the Asian crisis appeared to be changing only the regional causality pattern the additional impact of the Russian crisis appeared to have changed the causality pattern in an even less predictable way crossing continents at random and thus pointing to the important role of international financial markets in regional and global financial contagion.

\footnotetext{
${ }^{17}$ Edwards (2000) discusses the role of the Russian crisis that, in contrast to the Asian crises spread to Latin America
} 


\section{References}

Baig, T. and I. Goldfajn, 2001, The Russian default and the contagion to Brazil, in: S. Claessens and K. Forbes, International financial contagion (Kluwer Academic Publishers, Boston), 267-300.

Baig, T. and I. Goldfajn, 1999, Financial market contagion in the Asian crisis, IMF Staff Papers.46, No.2, 167-195.

Calvo, G.A, 1999, Contagion in emerging markets. When Wall Street is a carrier, University of Maryland, Draft: 2 May, mimeo.

Chowdhry, B. and A. Goyal, 2000, Understanding the financial crisis in Asia, Pacific-Basin Finance Journal 8, 135-152.

Claessens, S., R. Dornbusch, and Y.C. Park, 2001, Contagion: Why crises spread and how this can be stopped, in: S. Claessens and K. Forbes, International financial contagion (Kluwer Academic Publishers, Boston), 19-42.

Council of Economic Advisors, 1999, Economic report of the president, U.S. Government Printing Office (Washington D.C.)

Demetriades, P.O. and K.A. Hussein, 1996, Does financial development cause economic growth? Time-series evidence from 16 countries, Journal of Development Economics $51,387-411$.

Edwards, S., 2000, Contagion, World Economy 23, 873-900.

Eichengreen, B., A. K. Rose, and C. Wyplosz, 1996, Speculative attacks on pegged exchange rates. An empirical exploration with special reference to the European Monetary System, in: Canzoneri, M., W. Ethier and V. Grilli, eds., The New Transatlantic Economy (Cambridge University Press, Cambridge and New York), 191-228. 
Forbes, K. and R. Rigobon, 1999, No contagion, only interdependences: Measuring stock market co-movements, NBER Working Paper 7267.

Gelos, G. and R. Sahay, 2001, Financial market spillovers: How different are the transition economies, in: S. Claessens and K. Forbes, International financial contagion (Kluwer Academic Publishers, Boston), 329-366.

Glick, R. and A.K. Rose, 1999a, contagion and trade - why are currency crises regional?, Journal of International Money and Finance 18, 603-617

Glick, R. and A. K. Rose, 1999b, Why are currency crises contagious? Draft: August 1999, from A. K. Rose's homepage.

Granger, C.W.J., 1988, Some recent developments in a concept of causality, Journal of Econometrics 39, 199-211.

Granger, C.W.J., W-N. Huang, and C-W. Yang, 2000, A bivariate causality between stock prices and exchange rates: evidence from the recent Asian flu, The Quarterly Review of Economics and Finance 40, 337-354.

Krugman, P., 1999, Balance sheets, the transfer problem, and financial crises, in: P. Isard, A. Razin, A.K. Rose, eds., International finance and international crises: Essays in honor of Robert Flood, Jr. (International Monetary Fund, Washington D.C.).

MacDonald, R. and C. Kearney, 1987, On the specification of Granger-causality tests using the cointegration methodology, Economics Letters 25, 149-153.

Masson, P., 1998, Contagion, monsoonal effects, spillovers, and jumps between multiple equilibria, IMF Working Paper 98/142.

Obstfeld, M., 1994, The logic of currency crises, Cahiers Economique et Monétaires 43, 189213.

OECD 1995, OECD Economic Outlook December 1995. 
Park, Y.C. and C-Y. Song, 2001, Financial contagion in the east Asian crisis - with special reference to the Republic of Korea, in: S. Claessens and K. Forbes, International financial contagion (Kluwer Academic Publishers, Boston), 241-266.

Pesenti, P. and C. Tille, 2000, The economics of currency crises and contagion: An introduction, Federal Research Board of New York Economic Policy Review, September, 3-16.

Sbracia, M. and A. Zaghini, 2001, Expectations and information in second generation currency crises models, Economic Modelling 18, 203-222.

Sander, H., 1990, "Anpassung mit Wachstum" oder Schuldenerleichterungen? Die theoretischen Grundlagen einer verstärkten Kooperation von IWF und Weltbank, Kredit und Kapital 23, 1-29.

Sims, C.A., J.H. Stock, and M.W. Watson, 1990, Inference in linear time series models with some unit roots, Econometrica 58, 113-144.

Summers, L.H., 2000, International financial crisis: Causes, prevention, and cures, American Economic Review 90, 1-16.

Van Rijckeghem, C. and B. Weder, 2001, Sources of contagion: is it finance or trade?, Journal of International Economics 54, 293-308.

Van Rijckeghem, C. and B. Weder (1999), Financial Contagion: Spillovers through Banking Centers, Paper prepared for the November 19-20, 1999 joint WIDER and World Bank conference " Sources of Contagion: Is it Finance or Trade?" in Helsinki, Finland. 
Appendix

- insert Tables A1, A2, A3, A4 here - 
Table 1: Descriptive Statistics

\begin{tabular}{|c|c|c|c|c|c|c|c|c|c|c|c|}
\hline & Argentina & Brazil & Hungary & Indonesia & Korea & Malaysia & Mexico & Philippines & Poland & Thailand & Russia \\
\hline \multicolumn{12}{|l|}{ average spread } \\
\hline full period & 3.24 & 3.63 & -0.89 & 5.70 & 3.03 & 1.68 & 2.56 & 3.51 & 0.60 & 2.65 & 30.66 \\
\hline tranquil period & 2.82 & 1.33 & 0.75 & 1.12 & 0.53 & 0.37 & 2.12 & 1.72 & 0.40 & 0.51 & 5.19 \\
\hline crisis period & 2.50 & 1.98 & 0.83 & 4.67 & 3.23 & 1.38 & 1.96 & 3.18 & 0.45 & 3.06 & 5.67 \\
\hline transition period & 4.00 & 6.31 & -0.09 & 9.48 & 4.98 & 2.98 & 3.46 & 4.77 & 0.93 & 4.05 & 65.36 \\
\hline post-crisis period & 3.68 & 4.17 & -6.52 & 5.37 & 1.73 & 1.22 & 2.53 & 3.58 & 0.51 & 1.53 & 40.36 \\
\hline $\begin{array}{r}\text { change tranquil-to-post } \\
\text { crisis }\end{array}$ & $30 \%$ & $214 \%$ & $-969 \%$ & $379 \%$ & $226 \%$ & $230 \%$ & $19 \%$ & $108 \%$ & $28 \%$ & $200 \%$ & $678 \%$ \\
\hline \multicolumn{12}{|l|}{ median spread } \\
\hline full period & 3.25 & 2.99 & 0.65 & 5.67 & 2.13 & 1.27 & 2.25 & 3.55 & 0.52 & 1.71 & 12.14 \\
\hline tranquil period & 2.81 & 1.33 & 0.68 & 1.16 & 0.55 & 0.38 & 2.10 & 1.75 & 0.39 & 0.51 & 5.21 \\
\hline crisis period & 2.50 & 1.94 & 0.79 & 4.72 & 3.67 & 0.59 & 1.95 & 3.33 & 0.42 & 3.76 & 5.54 \\
\hline transition period & 3.93 & 6.29 & 0.37 & 9.48 & 4.65 & 2.97 & 3.46 & 4.27 & 0.86 & 3.99 & 69.11 \\
\hline post-crisis period & 3.57 & 3.97 & -6.00 & 5.26 & 1.70 & 1.27 & 2.38 & 3.56 & 0.44 & 1.65 & 40.78 \\
\hline $\begin{array}{r}\text { Change tranquil-to-post } \\
\text { crisis }\end{array}$ & $27 \%$ & $198 \%$ & $-982 \%$ & $353 \%$ & $209 \%$ & $234 \%$ & $13 \%$ & $103 \%$ & $13 \%$ & $224 \%$ & $683 \%$ \\
\hline \multicolumn{12}{|c|}{ standard deviation of bond spread } \\
\hline full period & 0.79 & 2.27 & 3.11 & 3.56 & 2.43 & 1.40 & 0.76 & 1.33 & 0.32 & 1.94 & 28.19 \\
\hline tranquil period & 0.33 & 0.33 & 0.15 & 0.21 & 0.09 & 0.05 & 0.22 & 0.14 & 0.09 & 0.08 & 0.50 \\
\hline crisis period & 0.38 & 0.91 & 0.21 & 2.66 & 1.83 & 1.08 & 0.25 & 0.76 & 0.17 & 1.38 & 2.01 \\
\hline transition period & 0.53 & 1.25 & 1.30 & 2.58 & 2.69 & 1.48 & 0.48 & 1.28 & 0.30 & 2.19 & 15.26 \\
\hline post-crisis period & 0.47 & 1.32 & 2.68 & 0.46 & 0.18 & 0.42 & 0.62 & 0.29 & 0.27 & 0.23 & 9.52 \\
\hline
\end{tabular}


Table 2: Intra-Asian Causality

\begin{tabular}{|c|c|c|c|c|c|c|c|c|c|c|c|c|}
\hline & \multicolumn{4}{|c|}{ Cointegration } & \multicolumn{8}{|c|}{ Causality } \\
\hline & \multirow{2}{*}{$\begin{array}{l}\text { tranquil } \\
\text { period }\end{array}$} & \multirow{2}{*}{$\begin{array}{l}\text { crisis } \\
\text { period }\end{array}$} & \multirow{2}{*}{$\begin{array}{l}\text { transition } \\
\text { period }\end{array}$} & \multirow{2}{*}{$\begin{array}{l}\text { post-crisis } \\
\text { period }\end{array}$} & \multicolumn{2}{|c|}{ tranquil period } & \multicolumn{2}{|c|}{ crisis period } & \multicolumn{2}{|c|}{ transition period } & \multicolumn{2}{|c|}{ post-crisis period } \\
\hline & & & & & short-term & ECM & short-term & ECM & short-term & ECM & short-term & ECM \\
\hline ind $\Rightarrow$ kor & no & no & no & yes & no & no & no & no & no & no & no & no \\
\hline ind $\Rightarrow$ mal & no & no & no & no & no & no & yes & no & yes & no & no & no \\
\hline ind $\Rightarrow$ phi & no & no & no & no & no & no & yes & no & no & no & (yes) & no \\
\hline ind $\Rightarrow$ tha & (yes) & no & no & (yes) & no & no & yes & no & yes & no & no & no \\
\hline kor $\Rightarrow$ mal & no & no & no & no & no & no & no & no & no & no & yes & no \\
\hline kor $\Rightarrow$ phi & (yes) & yes & no & no & no & no & (yes) & (yes) & no & no & no & no \\
\hline kor $\Rightarrow$ tha & yes & (yes) & no & yes & (yes) & yes & no & (yes) & yes & no & no & yes \\
\hline $\mathrm{mal} \Rightarrow$ ind & no & no & no & no & no & no & no & no & no & no & yes & no \\
\hline mal $\Rightarrow$ kor & no & no & no & yes & no & no & no & no & yes & no & (yes) & no \\
\hline mal $\Rightarrow$ phi & no & no & no & (yes) & no & no & no & no & no & no & yes & (yes) \\
\hline mal $\Rightarrow$ tha & no & no & no & yes & no & no & yes & no & no & no & no & no \\
\hline phi $\Rightarrow$ kor & (yes) & (yes) & no & yes & no & no & yes & yes & (yes) & no & (yes) & no \\
\hline phi $\Rightarrow$ mal & no & no & no & no & no & no & yes & no & no & no & (yes) & no \\
\hline phi $\Rightarrow$ tha & yes & (yes) & no & (yes) & yes & no & yes & yes & no & no & no & no \\
\hline tha $\Rightarrow$ ind & no & no & no & no & no & no & no & no & no & no & no & no \\
\hline tha $\Rightarrow$ kor & yes & (yes) & no & yes & no & no & no & yes & no & no & no & no \\
\hline tha $\Rightarrow$ mal & no & no & no & no & no & no & no & no & no & no & no & no \\
\hline tha $\Rightarrow$ phi & (yes) & (yes) & no & no & no & no & no & no & no & no & no & no \\
\hline \multicolumn{13}{|c|}{ number of country-pairs which show: } \\
\hline cointegration & 3 & 1 & 0 & 6 & \multirow{2}{*}{\multicolumn{2}{|c|}{2}} & \multirow{2}{*}{\multicolumn{2}{|c|}{9}} & \multirow{2}{*}{\multicolumn{2}{|c|}{6}} & \multirow{2}{*}{\multicolumn{2}{|c|}{5}} \\
\hline Granger-causality & & & & & & & & & & & & \\
\hline ECM-causality only & & & & & \multicolumn{2}{|c|}{1} & \multicolumn{2}{|c|}{1} & \multicolumn{2}{|c|}{0} & \multicolumn{2}{|c|}{2} \\
\hline
\end{tabular}

Note: Regarding cointegration, "x $\Rightarrow y^{\prime}$ indicates a cointegrating relationship described as $\mathrm{y}_{\mathrm{t}}=\mathrm{a}+\mathrm{b} \mathrm{x}_{\mathrm{t}}$. For Granger Causality "x $\Rightarrow \mathrm{y}$ " should be read as $\mathrm{x}$ causing $\mathrm{y}$. Brackets

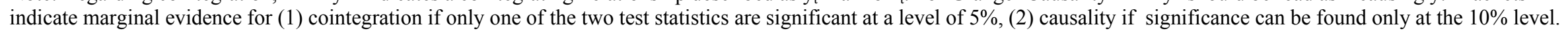


Table 3: Causality between Asia and other emerging economies

\begin{tabular}{|c|c|c|c|c|c|c|c|c|c|c|c|c|}
\hline & \multicolumn{4}{|c|}{ Cointegration } & \multicolumn{8}{|c|}{ Causality } \\
\hline & \multirow{2}{*}{$\begin{array}{c}\text { tranquil } \\
\text { period }\end{array}$} & \multirow{2}{*}{$\begin{array}{l}\text { crisis } \\
\text { period }\end{array}$} & \multirow{2}{*}{$\begin{array}{c}\text { transition } \\
\text { period }\end{array}$} & \multirow{2}{*}{$\begin{array}{l}\text { post-crisis } \\
\text { period }\end{array}$} & \multicolumn{2}{|c|}{ tranquil period } & \multicolumn{2}{|c|}{ crisis period } & \multicolumn{2}{|c|}{ transition period } & \multicolumn{2}{|c|}{ post-crisis period } \\
\hline & & & & & short-term & ECM & short-term & ECM & short-term & $\mathrm{ECM}$ & short-term & ECM \\
\hline rus $\Rightarrow$ ind & no & no & no & no & no & no & no & no & yes & no & no & no \\
\hline ind $\Rightarrow$ rus & no & no & no & no & no & no & (yes) & no & no & no & no & no \\
\hline hun $\Rightarrow$ ind & no & no & no & no & no & no & (yes) & no & no & no & no & no \\
\hline ind $\Rightarrow$ hun & no & (yes) & no & no & no & no & no & no & (yes) & no & (yes) & no \\
\hline pol $\Rightarrow$ ind & no & no & no & no & no & no & no & no & no & no & no & no \\
\hline ind $\Rightarrow$ pol & yes & (yes) & no & no & no & yes & yes & no & no & no & no & no \\
\hline ind $\Rightarrow$ arg & no & no & no & no & no & no & no & no & no & no & no & no \\
\hline bra $\Rightarrow$ ind & no & no & no & (yes) & no & no & no & no & yes & no & no & yes \\
\hline ind $\Rightarrow$ bra & no & no & no & no & (yes) & no & no & no & no & no & no & no \\
\hline mex $\Rightarrow$ ind & no & no & no & (yes) & (yes) & no & no & no & yes & no & no & yes \\
\hline ind $\Rightarrow \operatorname{mex}$ & no & (yes) & no & no & no & no & no & no & no & no & no & no \\
\hline rus $\Rightarrow$ kor & no & no & no & yes & no & no & yes & no & no & no & no & no \\
\hline kor $\Rightarrow$ rus & no & no & no & yes & no & no & no & no & no & no & no & no \\
\hline hun $\Rightarrow$ kor & yes & no & no & yes & no & yes & no & no & no & no & no & no \\
\hline pol $\Rightarrow$ kor & no & no & no & (yes) & no & no & (yes) & no & yes & no & yes & yes \\
\hline kor $\Rightarrow$ pol & (yes) & (yes) & no & yes & no & (yes) & no & no & no & no & no & no \\
\hline $\arg \Rightarrow$ kor & no & no & no & (yes) & no & no & yes & no & yes & no & yes & yes \\
\hline kor $\Rightarrow \arg$ & no & no & no & yes & no & no & no & no & yes & no & no & yes \\
\hline bra $\Rightarrow$ kor & no & no & no & yes & (yes) & no & yes & no & yes & no & yes & yes \\
\hline kor $\Rightarrow$ bra & no & (yes) & no & yes & no & no & no & no & no & no & no & no \\
\hline mex $\Rightarrow$ kor & no & no & no & yes & yes & no & yes & no & yes & no & yes & yes \\
\hline kor $\Rightarrow \operatorname{mex}$ & no & (yes) & no & yes & no & no & no & no & yes & no & no & no \\
\hline rus $\Rightarrow$ mal & no & no & no & no & yes & no & no & no & no & no & (yes) & no \\
\hline mal $\Rightarrow$ rus & no & no & no & no & yes & no & no & no & no & no & no & no \\
\hline hun $\Rightarrow$ mal & no & no & no & no & no & no & no & no & no & no & no & no \\
\hline mal $\Rightarrow$ hun & no & (yes) & no & no & no & no & no & yes & no & no & no & no \\
\hline pol $\Rightarrow$ mal & no & no & no & no & no & no & no & no & no & no & yes & no \\
\hline mal $\Rightarrow$ pol & no & (yes) & no & no & no & no & no & no & no & no & no & no \\
\hline $\arg \Rightarrow$ mal & no & no & no & no & no & no & no & no & no & no & no & no \\
\hline mal $\Rightarrow$ arg & no & no & no & no & no & no & no & no & yes & no & no & no \\
\hline bra $\Rightarrow$ mal & no & no & no & no & no & no & no & no & no & no & no & no \\
\hline mal $\Rightarrow$ mex & no & no & no & no & no & no & no & no & yes & no & no & no \\
\hline
\end{tabular}




\begin{tabular}{|c|c|c|c|c|c|c|c|c|c|c|c|c|}
\hline & \multicolumn{4}{|c|}{ Cointegration } & \multicolumn{8}{|c|}{ Causality } \\
\hline & \multirow{2}{*}{$\begin{array}{c}\text { tranquil } \\
\text { period }\end{array}$} & \multirow{2}{*}{$\begin{array}{c}\text { crisis } \\
\text { period }\end{array}$} & \multirow{2}{*}{$\begin{array}{c}\text { transition } \\
\text { period }\end{array}$} & \multirow{2}{*}{$\begin{array}{c}\text { post-crisis } \\
\text { period }\end{array}$} & \multicolumn{2}{|c|}{ tranquil period } & \multicolumn{2}{|c|}{ crisis period } & \multicolumn{2}{|c|}{ transition period } & \multicolumn{2}{|c|}{ post-crisis period } \\
\hline & & & & & short-term & ECM & short-term & $\mathrm{ECM}$ & short-term & $\mathrm{ECM}$ & short-term & $\mathrm{ECM}$ \\
\hline rus $\Rightarrow$ phi & (yes) & no & no & no & yes & no & yes & no & no & no & no & no \\
\hline phi $\Rightarrow$ rus & no & no & no & no & no & no & no & no & no & no & no & no \\
\hline hun $\Rightarrow$ phi & yes & no & no & no & no & yes & no & no & no & no & no & no \\
\hline phi $\Rightarrow$ hun & yes & no & no & no & no & yes & no & no & yes & no & no & no \\
\hline pol $\Rightarrow$ phi & no & no & no & no & no & no & no & no & yes & no & no & no \\
\hline phi $\Rightarrow$ pol & (yes) & yes & no & no & no & (yes) & no & no & (yes) & no & no & no \\
\hline arg $\Rightarrow$ phi & no & yes & no & no & yes & no & yes & yes & yes & no & no & no \\
\hline phi $\Rightarrow$ arg & no & yes & no & no & no & no & no & yes & yes & no & no & no \\
\hline bra $\Rightarrow$ phi & no & yes & no & no & yes & no & yes & no & yes & no & no & no \\
\hline phi $\Rightarrow$ bra & no & yes & no & no & no & no & no & no & yes & no & (yes) & no \\
\hline mex $\Rightarrow$ phi & no & yes & no & no & yes & no & yes & no & yes & no & no & no \\
\hline phi $\Rightarrow$ mex & no & yes & no & no & no & no & no & no & yes & no & no & no \\
\hline rus $\Rightarrow$ tha & yes & no & no & (yes) & yes & no & yes & no & no & no & no & yes \\
\hline tha $\Rightarrow$ rus & no & no & no & no & no & no & no & no & no & no & no & no \\
\hline hun $\Rightarrow$ tha & (yes) & no & no & yes & no & (yes) & no & no & no & no & no & yes \\
\hline tha $\Rightarrow$ hun & yes & no & no & no & no & (yes) & no & no & no & no & yes & no \\
\hline pol $\Rightarrow$ tha & yes & no & no & no & no & no & yes & no & no & no & yes & no \\
\hline tha $\Rightarrow$ pol & yes & (yes) & no & no & no & yes & no & no & no & no & no & no \\
\hline arg $\Rightarrow$ tha & yes & no & no & no & no & no & yes & no & no & no & no & no \\
\hline tha $\Rightarrow$ arg & no & no & no & no & no & no & no & no & no & no & no & no \\
\hline bra $\Rightarrow$ tha & yes & no & no & no & no & no & yes & no & no & no & yes & no \\
\hline tha $\Rightarrow$ bra & no & no & no & no & no & no & no & no & no & no & no & no \\
\hline mex $\Rightarrow$ tha & (yes) & no & no & no & no & no & yes & no & no & no & yes & no \\
\hline tha $\Rightarrow$ mex & no & (yes) & no & no & no & no & no & no & no & no & no & no \\
\hline number of country-p & hich show: & & & & & & & & & & & \\
\hline cointegration & 11 & 7 & 0 & 11 & & & & & & & & \\
\hline Granger-causality & & & & & 1 & & 15 & & & & & \\
\hline ECM-causality only & & & & & trat & & 2 & & & & & \\
\hline
\end{tabular}


Table A1: Sample Description

\begin{tabular}{lll}
\hline Country & Abbreviation & Selected Datastream bond series \\
\hline Argentina & arg & ARGENTINA-PAR 1993 G/R 31/03/23 S \\
Brazil & bra & BRAZIL-C BD.(SR-L)FLIRB. 5\% 15/04/04-14 STEP-UP \\
Hungary & hun & HUNG.STE.DEV.INST. $1990101 / 2 \% 31 / 08 / 00$ \\
Indonesia & ind & INDONESIA 1996 7 3/4\% 01/08/06 S \\
Korea & kor & KOREA DEV.BANK 1995 6 1/2\% 15/11/02 S \\
Malaysia & mal & MALAYSIA 1990 $97 / 8 \%$ 27/09/00 S \\
Mexico & mex & MEXICO-PAR (B TO Q) VRR. 6 1/4\% 31/12/19 S \\
Philippines & phi & PHILIPPINES 1996 $83 / 4 \%$ 07/10/16 \\
Russia & rus & RUSSIA 1993 3\% 14/05/03 \\
Poland & pol & POLAND-PAR 1994 3\% $(2.75)$ 27/10/24 STEP-UP \\
Thailand & tha & THAILAND P92 $81 / 4 \% 15 / 03 / 02$ \\
\hline
\end{tabular}

Note: Naming conventions for bonds on Datastream are such that the issuer, the issue date, the coupon rate and the maturity are reported in sequence. 
Table A2: Unit root tests

\begin{tabular}{|c|c|c|c|c|c|c|c|c|c|c|c|c|}
\hline \multirow[t]{2}{*}{ bond series } & \multicolumn{3}{|c|}{ tranquil period } & \multicolumn{3}{|c|}{ crisis period } & \multicolumn{3}{|c|}{ transition period } & \multicolumn{3}{|c|}{ post-crisis period } \\
\hline & $\begin{array}{l}\text { level } \\
\mathrm{t}\left(\delta_{1}\right)\end{array}$ & $\begin{array}{c}1^{\text {st }} \\
\text { differences } \\
\mathrm{t}\left(\delta_{1}\right)\end{array}$ & $\mathrm{I}(\mathrm{d})$ & $\begin{array}{l}\text { level } \\
\mathrm{t}\left(\delta_{1}\right)\end{array}$ & $\begin{array}{c}1^{\text {st }} \\
\text { differences } \\
\mathrm{t}\left(\delta_{1}\right)\end{array}$ & $\mathrm{I}(\mathrm{d})$ & $\begin{array}{l}\text { level } \\
\mathrm{t}\left(\delta_{1}\right)\end{array}$ & $\begin{array}{c}1^{\text {st }} \\
\text { differences } \\
\mathrm{t}\left(\delta_{1}\right)\end{array}$ & $\mathrm{I}(\mathrm{d})$ & $\begin{array}{l}\text { level } \\
\mathrm{t}\left(\delta_{1}\right)\end{array}$ & $\begin{array}{c}1^{\text {st }} \\
\text { differences } \\
\mathrm{t}\left(\delta_{1}\right)\end{array}$ & $\mathrm{I}(\mathrm{d})$ \\
\hline \multicolumn{13}{|c|}{ Asian country bonds: } \\
\hline Indonesia & -2.12 & -8.33 & $\mathrm{I}(1)$ & -1.41 & -13.27 & $\mathrm{I}(1)$ & -1.87 & -10.39 & $\mathrm{I}(1)$ & -1.13 & -10.50 & $\mathrm{I}(1)$ \\
\hline Korea & -2.10 & -13.10 & $\mathrm{I}(1)$ & -1.52 & -10.58 & $\mathrm{I}(1)$ & -0.59 & -13.00 & $\mathrm{I}(1)$ & -2.30 & -12.74 & $\mathrm{I}(1)$ \\
\hline Malaysia & $-6.36^{*}$ & -12.48 & $\mathrm{I}(0)$ & -0.50 & -13.63 & $\mathrm{I}(1)$ & -0.99 & -11.60 & $\mathrm{I}(1)$ & -2.49 & -9.09 & $\mathrm{I}(1)$ \\
\hline Philippines & -2.24 & -8.70 & $\mathrm{I}(1)$ & -2.39 & -16.94 & $\mathrm{I}(1)$ & -1.21 & -9.96 & $\mathrm{I}(1)$ & -2.28 & -8.96 & $\mathrm{I}(1)$ \\
\hline Thailand & $-2.74 * * *$ & -13.54 & $\mathrm{I}(1)$ & -1.79 & -12.31 & $\mathrm{I}(1)$ & -1.15 & -11.55 & $\mathrm{I}(1)$ & -1.24 & -11.57 & $\mathrm{I}(1)$ \\
\hline \multicolumn{13}{|c|}{ Non-Asian country bonds: } \\
\hline Russia & -1.02 & -9.29 & $\mathrm{I}(1)$ & -0.50 & -11.19 & $\mathrm{I}(1)$ & $-3.35 * *$ & -11.10 & $\mathrm{I}(0)$ & -0.96 & -9.43 & $\mathrm{I}(1)$ \\
\hline Hungary & -2.17 & -12.62 & $\mathrm{I}(1)$ & -2.31 & -11.77 & $\mathrm{I}(1)$ & $2.35^{*}$ & -11.08 & $\mathrm{I}(0)$ & -0.16 & -10.53 & $\mathrm{I}(1)$ \\
\hline Poland & -2.41 & -9.91 & $\mathrm{I}(1)$ & $-2.86 * * *$ & -12.25 & $\mathrm{I}(1)$ & $-6.25^{*}$ & -17.22 & $\mathrm{I}(0)$ & -1.47 & -12.43 & $\mathrm{I}(1)$ \\
\hline Argentina & -1.88 & -8.36 & $\mathrm{I}(1)$ & $-2.70 * * *$ & -11.18 & $\mathrm{I}(1)$ & $-3.42 * *$ & -12.05 & $\mathrm{I}(0)$ & -1.45 & -11.10 & $\mathrm{I}(1)$ \\
\hline Brazil & $-2.63 * * *$ & -8.27 & $\mathrm{I}(1)$ & -1.98 & -11.95 & $\mathrm{I}(1)$ & $-3.40 * *$ & -11.89 & $\mathrm{I}(0)$ & -0.95 & -9.78 & $\mathrm{I}(1)$ \\
\hline Mexico & -1.82 & -8.58 & $\mathrm{I}(1)$ & -1.91 & -14.37 & $\mathrm{I}(1)$ & $-3.14 * *$ & -11.70 & $\mathrm{I}(0)$ & -0.55 & -9.79 & $\mathrm{I}(1)$ \\
\hline
\end{tabular}

Note: The t-test refers to the null hypothesis $\mathrm{H}_{0}: \delta_{1}=0$ for the level regression $\Delta \mathrm{X}_{\mathrm{t}}=\delta_{\mathrm{X}, 0}+\delta_{\mathrm{X}, 1} \mathrm{X}_{\mathrm{t}-1}+\delta_{\mathrm{X}, 2} \Delta \mathrm{X}_{\mathrm{t}-2}+\varepsilon_{\mathrm{X}, \mathrm{t}}$ and first differences regression $\Delta^{2} X_{t}=\delta_{X, 0}+\delta_{X, 1} \Delta X_{t-1}+\delta_{X, 2} \Delta^{2} X_{t-2}+\varepsilon_{X, t}$. Based on 100 observations, the critical values are $-3.46(1 \%),-2.88(5 \%)$, and $-2.57(10 \%)$. For the $1^{\text {st }}$ differences regression, the t-test is always significant. For the level regressions, significance is indicated with *, $* *$, and *** reflecting the $1 \%, 5 \%$, and $10 \%$ level respectively. 
Table A3: Cointegration analysis inside Asia

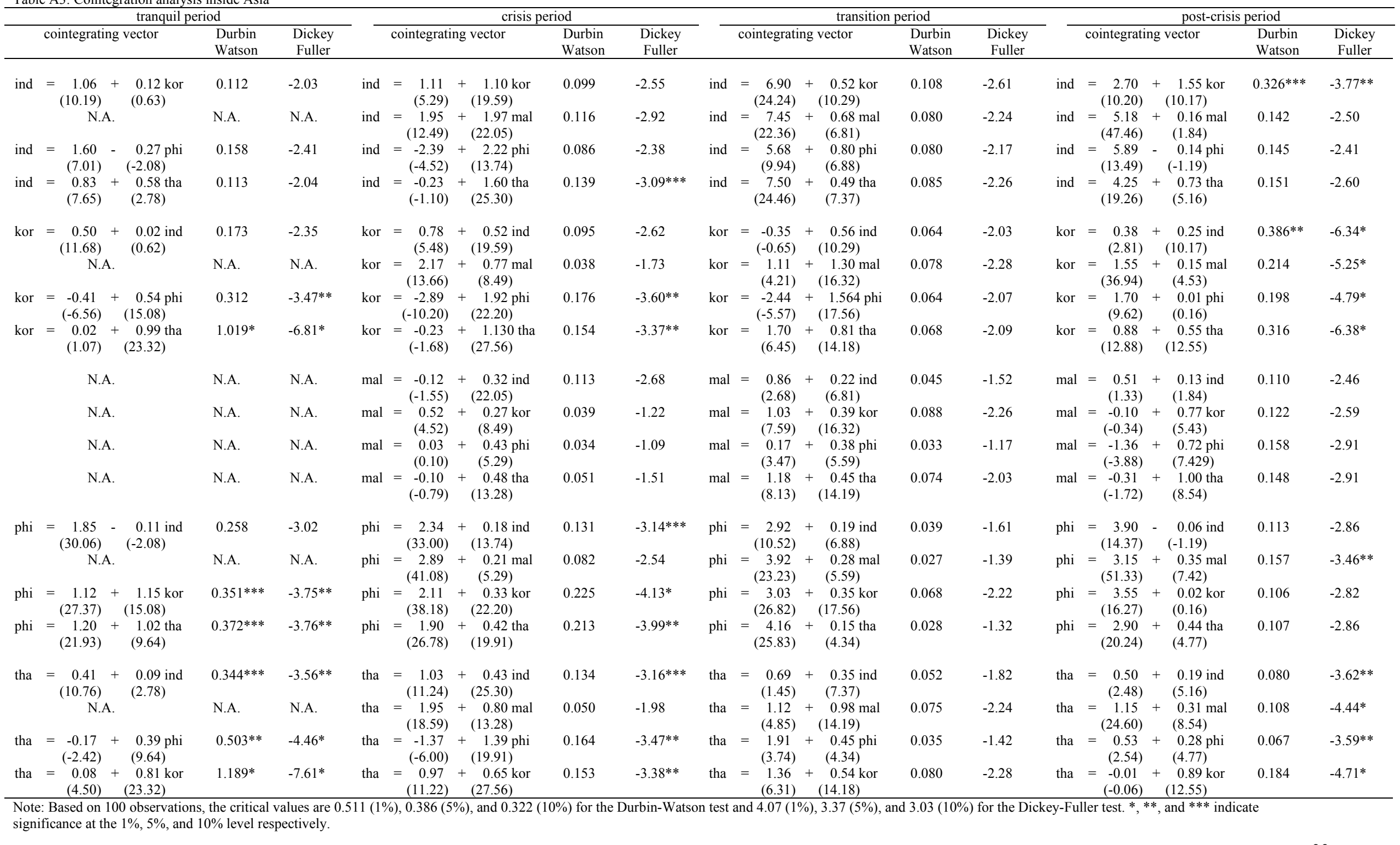


Table A4: Granger-causality inside Asia

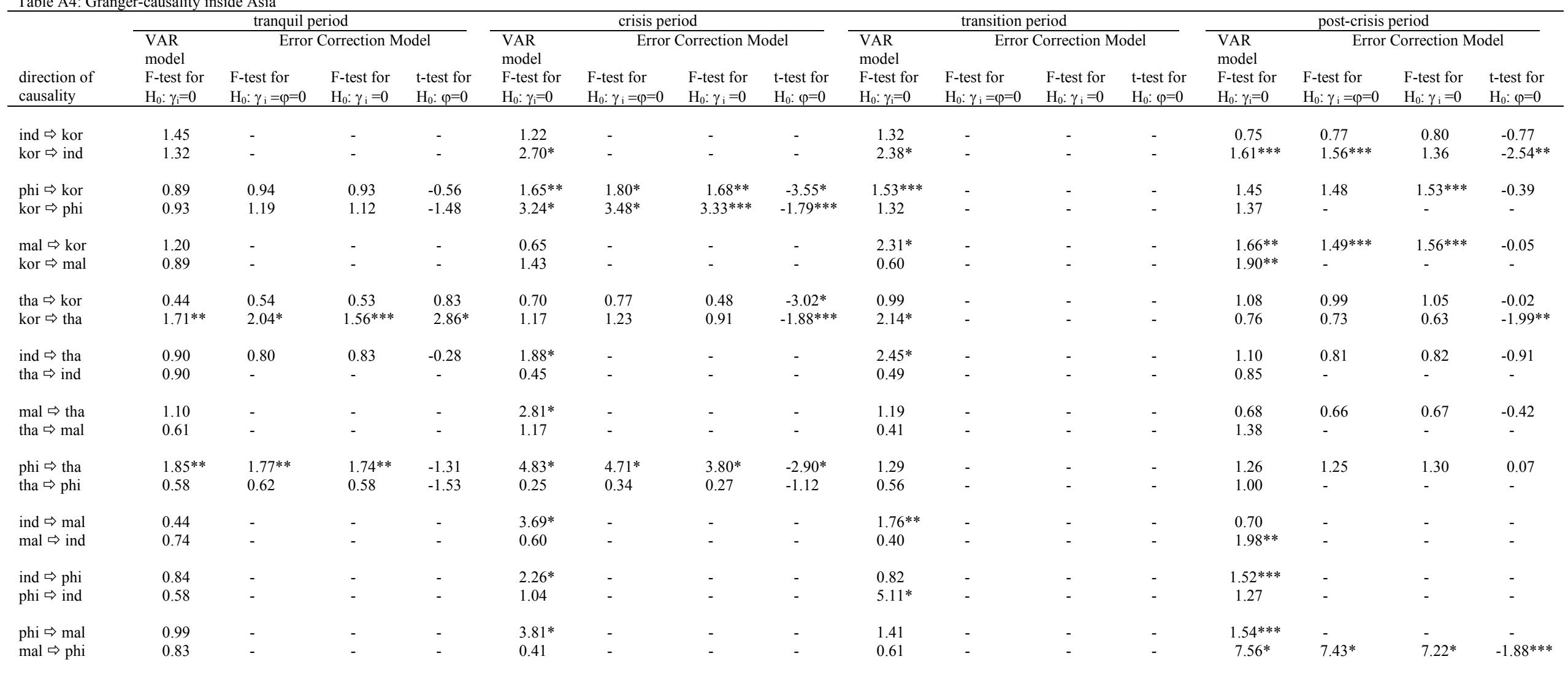

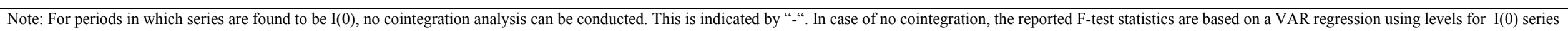

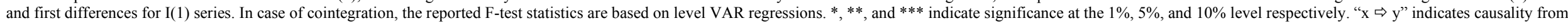
$\mathrm{x}$ to $\mathrm{y}$. 


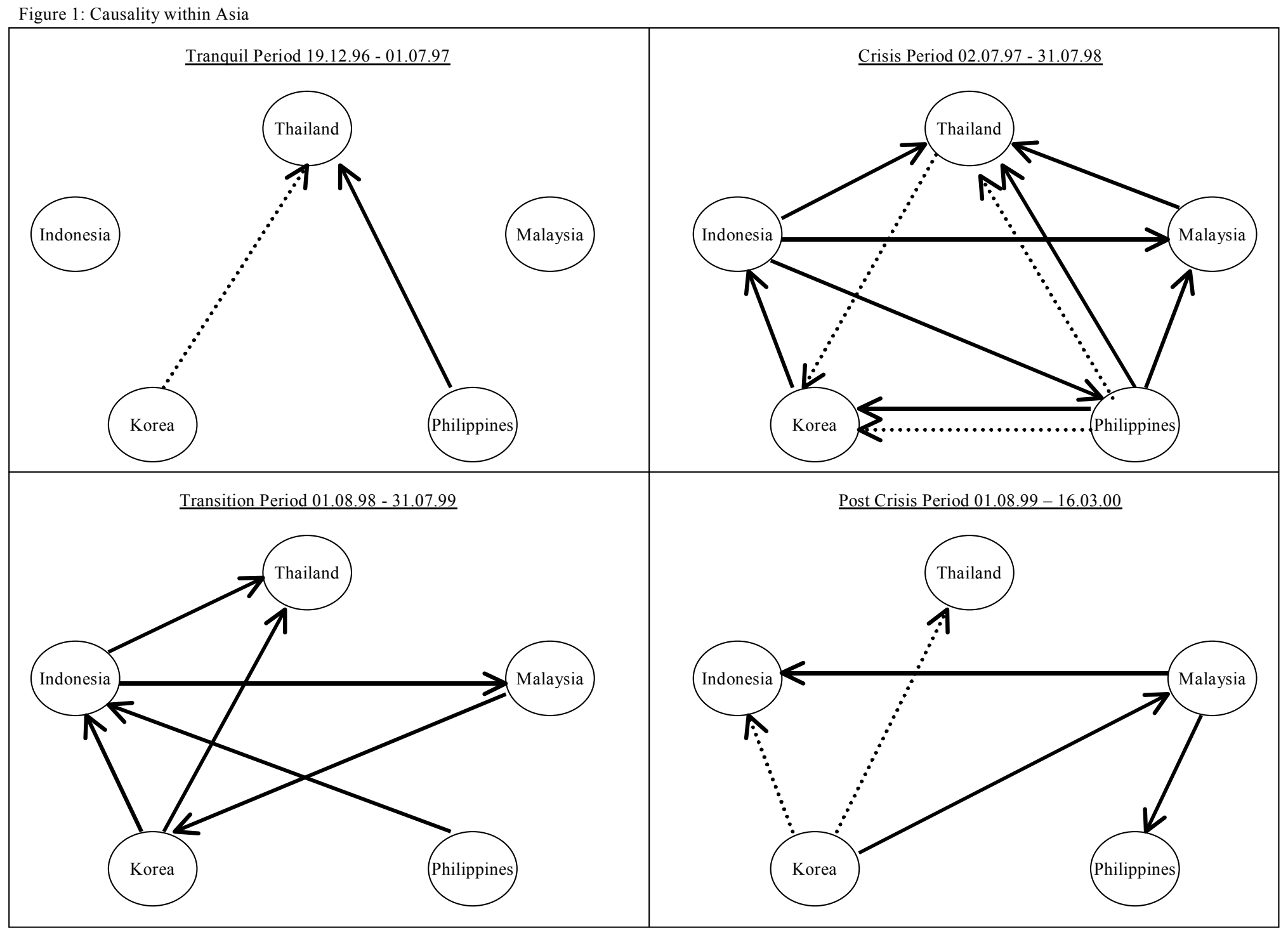

Note: Solid arrows indicate a short-term causality whereas dotted arrowsindicate long-term causality at a significance level of at least $5 \%$. 